\title{
ANALISIS PENGEMBANGAN WISATA LUAK GADANG BUKIK BAKA UNTUK MENINGKATKAN DAYA TARIK WISATA DI KABUPATEN AGAM, SUMATERA BARAT
}

\author{
VINA KUMALA, DEWI ANGGRAINI \\ Universitas Muhammadiyah Sumatera Barat \\ vinakumala17@gmail.com, dewianggraini2606@gmail.com
}

\begin{abstract}
Luak Gadang Bukik Baka is a natural tourist attraction located in Agam Regency, West Sumatra. This tourist attraction is relatively new, so it is still managed by the community. An attraction that is favored by this tourist attraction is a fish pond with a karst cliff on one side. Bukik Baka is a beautiful hill that has lovely sees and can also be used as a camping site. This tourist attraction is still in the early stages of growth. Since opening in April 2018, the available tourist facilities are still minimal, but tourist visits to this tourist attraction are very busy. This study aims to figure out how to develop the tourism potential of Luak Gadang Bukik Baka, so that it can attract tourist visits to Jorong Guguak Rangpisang, Nagari Kamang Hilia, Agam Regency. The research approach used is the qualitative descriptive method. Obtaining the informant's researchers used the snowball technique. Observation, question, and answer (interview), and recording were used as data collection techniques. Based on the findings of the study, it can be inferred that the current innovations are in the areas of activities and services, such as lodging and facilities. Meanwhile, Luak Gadang Bukik Baka has not fully evolved in terms of physical aspects, beauty, accessibility, socio-economic, and cultural aspects. It is hoped that the Agam Regency Government will continue to support the Jorong Guguak Rangpisang community in developing the Luak Gadang Bukik Baka into a popular tourist destination.
\end{abstract}

Keywords: Development, Tourist Object

Abstrak: Luak Gadang dan Bukik Baka adalah natural tourism yang berlokasi di Kabupaten Agam, Sumatera Barat. Tempat wisata ini tergolong baru sehingga masih dikelola oleh masyarakat. Atraksi yang diunggulkan oleh objek wisata ini adalah sebuah sebuah kolam ikan yang salah satu sisinya terdapat tebing batu karst. Bukik Baka merupakan sebuah bukit yang memiliki pemandangan yang indah dan dapat digunakan sebagai tempat berkemah. Hingga saat ini objek wisata tersebut masih dalam tahap pengembangan. Sejak dibuka pada bulan April 2018, fasilitas wisata yang tersedia masih minim, namun kunjungan wisatawan ke objek wisata ini sangat ramai. Penelitian ini bertujuan untuk mengetahui bagaimana cara mengembangkan potensi wisata Luak Gadang Bukik Baka, sehingga dapat menarik kunjungan wisatawan ke Jorong Guguak Rangpisang, Nagari Kamang Hilia, Kabupaten Agam. Pendekatan penelitian yang digunakan adalah metode deskriptif kualitatif. Untuk mendapatkan informan peneliti menggunakan teknik bola salju. Observasi, tanya jawab (wawancara), dan pencatatan digunakan sebagai teknik pengumpulan data. Menurut kajian hasil penelitian didapatkan konklusi bahwa perkembangan yang dilakukan adalah pada aspek aktifitas dan fasilitas, seperti penginapan dan fasilitasnya. Sedangkan Luak Gadang Bukik Baka belum sepenuhnya berkembang baik dari aspek fisik, keindahan, aksesibilitas, sosial ekonomi, dan budaya. Pemerintah Kabupaten Agam diharapkan terus mendukung masyarakat Jorong Guguak Rangpisang dalam mengembangkan Luak Gadang Bukik Baka menjadi destinasi wisata yang populer.

Kata Kunci: Pengembangan, Objek Wisata 


\section{A. Pendahuluan}

Pariwisata adalah salah satu sektor yang sudah terbukti dapat meningkatkan pendapatan ekonomi diberbagai dunia. Sehingga sektor ini sedang menjadi primadona dibanyak negara, termasuk Indonesia. Provinsi Sumatera Barat adalah satu diantara banyak provinsi yang ada di Indonesia yang juga menyasar sektor pariwisata sebagai sektor unggulannya. Provinsi ini memiliki bentang alam berupa daratan dan lautan dengan berjuta keindahan yang berpotensi menjadi destinasi wisata. Setiap kota dan kabupaten di Sumatera Barat juga memiliki beragam keindahan alam, sejarah, dan budaya, yang berpotensi untuk dijadikan keunggulan pariwisataannya, sehingga bisa ikut berperan sebagai sektor yang mampu menyumbangkan naiknya angka pendapatan daerah dan juga berdampak positif bagi keberlangsungan ekonomi masyarakat di Sumatera Barat.

Salah satu daerah yang ikut memberi kontribusi pada sektor pariwisata di Sumatera Barat ini adalah Kabupaten Agam. Kabupaten ini dikenal memiliki banyak daya tarik wisata alam, budaya, sejarah, dan wisata buatan. Beberapa objek wisata tersebut antara lain man made attraction seperti Greenhouse Lezatta, natural tourism seperti Danau Maninjau, Tarusan Kamang, serta obejek wisata yang merupakan perpaduan antara natural tourism dan man made attraction yaitu Luak Gadang dan Bukit Baka, destinasi ini termasuk objek wisata baru yang cukup ramai dikunjungi wisatawan saat ini. Luak Gadang dan Bukit Baka berada di daerah yang bernama Jorong Guguak Rang Pisang, Kabupaten Agam. Wisatawan lokal biasanya juga mengenal daerah ini dengan sebutan Nagari Kamang Hilia atau Kamang Magek.

Pada aspek ekonomi, nilai jual objek wisata Luak Gadang cukup berpotensi tinggi untuk meningkatkan kepariwisataan daerah dengan berbagai keunikan yang menjadi daya tarik. Objek wisata alam yang dipadukan dengan atraksi buatan ini dapat ditempuh sekitar 40 menit dari Kota Bukittinggi dengan jarak kurang lebih 17 kilometer. Luak Gadang dan Bukit Baka diperkirakan memiliki luas satu hektar (1Ha), dan seluruh kegiatan operasionalnya masih diselenggarakan oleh masyarakat daerah. Beberapa atraksi yang terdapat di objek wisata ini antara lain dua buah kolam ikan dengan air berwarna biru dan hiasan tebing batu gamping (Karts) atau batu kapur bercelah kecil berbentuk pori-pori yang artistik dan menawan disalah satu sisinya. Disela-sela dua buah kolam tersebut tampak jalan selebar satu meter yang merupakan akses lintasan ke atas Bukit Baka. Bukit ini memiliki luas puncak sekitar $500 \mathrm{~m}^{2}$, dan dapat ditempuh sekitar 20 menit dari Luak Gadang. Pada puncak Bukik Baka, wisatawan dapat menikmati keindahan sekitar Nagari Kamang, atau mengikuti atraksi wisata adventure seperti camping dan hiking. Jalur pendakian (hiking track) yang disediakan untuk naik ke puncak bukit juga sangat aman dan sesuai untuk wisatawan berusia tua ataupun muda, sehingga tentu saja dapat menarik minat wisatawan dalam negeri maupun mancanegara untuk menikmati keindahan Nagari Kamang dari ketinggian bukit tersebut. Pada objek wisata ini juga disediakan beberapa rakit apung yang dapat digunakan oleh wisatawan tanpa dikenakan biaya atau gratis. Selain itu, dari segi cultural tourism juga dapat disaksikan berbagai atraksi asli daerah seperti interaksi sosial kehidupan masyarakat desa yang memiliki budaya ramah tamah, gotong royong, dan religious.

Berdasarkan hasil observasi di Luak Gadang dan Bukit Baka, banyak potensi alam yang memerlukan pengembangan untuk dijadikan atraksi wisata. Pengembangan merupakan suatu tindakan dengan cara dan proses-proses tertentu untuk membuat 
sesuatu menjadi lebih baik, maju, berguna, dan sempurna. Sementara itu pengembangan pariwisata adalah suatu usaha yang dilakukan pihak terkait dalam rangka melengkapi serta meningkatkan sarana prasarana seperti fasilitas maupun pelayanan yang diperlukan wisatawan. Beberapa aspek yang berpengaruh dalam kegiatan pengembangan sebuah destinasi wisata antara lain peningkatan atraksi, promosi dan pemasaran, pasar wisata, transportasi dan masyarakat (Darminta, 2002, dalam Wulandari, 2015; Pearce, 1981; Hadinoto, 1996).

Kondisi yang ada saat ini pengembangan Bukit Baka dilakukan oleh masyarakat setempat dan pemuka nagari yang disebut sebagai wali jorong selaku pengawas. Beberapa pengembangan tersebut berupa infrastruktur penunjang pariwisata, seperti pengecoran akses jalan menuju ke lokasi wisata yang dananya didapatkan dari sumbangan masyarakat Nagari Kamang. Sementara itu dukungan dari Pemerintah Kabupaten yang didapatkan adalah bantuan heavy equipment atau alat-alat berat seperti excavator yang digunakan untuk mengorek kedua kolam agar lebih dalam sehingga air kolam tersebut menjadi lebih jernih. Kemudian pemerintah juga menyumbangkan benih ikan sejumlah 32 ribu ekor berjenis oreochromis niloticus atau dikenal dengan nama ikan nila, serta berbagai jenis bibit bunga untuk menambah keindahan objek wisata tersebut.

\section{B. Metodologi Penelitian}

Metode yang digunakan dalam kajian ini digolongkan kepada penelitian kualitatif dengan analisis deskriptif. Tujuan utama penelitian ini untuk mengkaji prosedur pengembangan sebuah objek wisata yang bernama Luak Gadang dan Bukit Baka. Observasi awal diketahui bahwa selama ini Luak Gadang telah digarap oleh pemerintah daerah dan masyarakat Korong Guguak Rangpisang. Informan ditentukan berdasarkan pertimbangan peneliti dengan menggunakan teknik sampling snowball sampling, yang mana narasumber selanjutnya didapat berdasarkan petunjuk dari narasumber sebelumnya. Data didapatkan melalui observasi langsung dan wawancara kepada informan berdasarkan pedoman wawancara yang telah diberikan sebelumnya. Menurut Noor (2011) alat yang banyak dipakai dalam membuktikan keabsahan sebuah informasi, berita, dan keterangan yang didapatkan atau dikenal juga dengan istilah recekhing adalah wawancara. Penulis dalam kegiatan ini menentukan narasumber kunci dengan beberapa pertimbangan. Narasumber kunci yang di tetapkan yaitu Pemerintah Daerah (Pemda), wali jorong, serta wali nagari. Pertanyaan yang telah ditetapkan sesuai variabel penelitian kemudian diberikan secara langsung, kemudian narasumber/informan juga membantu memberi rekomendasi siapa saja orang yang kompeten untuk dapat dijadikan informan berikutnya. Pada proses mengumpulkan data dalam penelitian ini, teknik yang dilakukan adalah mengamati dan mencatat segala hal yang berhubungan dengan objek maupun subjek penelitian, mengkaji berbagai arsip penting, dan mengabadikan kondisi lapangan dengan kamera sebagai berkas dokumentasi. Data penelitian yang diperoleh akan diproses melalui pengorganisasian dan pengurutan yang dimasukkan ke dalam sebuah pola, kemudian data diberikan pengelompokan dan uraian satuan dasar, sampai tema dapat ditemukan dan tempat perancangan hipotesis kerja seperti perekomendasian data (Moleong, 2004). Pada penelitian ini teknik analisis data yang diterapkan yaitu interaktif analisis. Triangulasi data diterapkan pada penelitian ini untuk keabsahan data. Moleong (2011) menjelaskan triangulasi merupakan suatu cara untuk mengkoreksi kesahihan data yang mengunakan selain diluar data itu untuk kebutuhan pengkoreksian atau sebagai pembeda terhadap data itu. Melalui sumber teknik triangulasi, peneliti melakukan pembandingan data E-ISSN: 2657-0300 Lembaga Penelitian dan Penerbitan Hasil Penelitian Ensiklopedia $\quad 221$ 
yang didapatkan dari berbagai sumber data untuk mengetahui kesahihan data yang diperoleh. Kemudian juga dilakukan cek ulang menggunkan triangulasi metode, dimana dilakukan pengkoreksian penelitian dengan teknik pengumpulan data yang tidak sama yakni studi dokumentasi dan observasi sehingga valid dan memperoleh derajat kepercayaan.

\section{Hasil dan Pembahasan}

Luak Gadang Bukik Baka merupakan sebuah kawasan hiburan yang baru dibuka untuk semua kalangan pada bulan April 2018 dengan wisata alam sebagai konsep. Berdasarkan hasil telaah menunjukkan bahwa pada pemekaran daya tarik wisata Luak Gadang Bukik Baka masih berfokus pada aspek atraksi dan fasilitas pada saat ini. Namun dari segi elemen fisik, elemen daya tarik dan aspek aksesbilitias dan elemen ekonomi sosial dan budaya belum terlihat pemekaran secara baik. Menurut hasil penggalian diperoleh bahwa Luak Gadang Buki Baka tidak mencukupi indikator ekspansi yang terdiri dari lima aspek sebagaimana dikemukakkan oleh Lestari (2013) perspekti-perspektif pendukung yang dibutuhkan pada pengembangan seperti perspekti fisik, perspektif daya tarik, perspektif aksesbilitas, perspektif aktivitas dan fasilitas, dan perspektif budaya sosial dan ekonomi.

\section{Aspek Fisik}

Pada perspektif fisik Luak Bukik kurang memenuhi pada geografi segemen geografi yang terdiri dari besarnya wilayah daerah tujuan wisata, besarnya keterpakaian area dan juga lingkar alam serta batas administrasi. Dimana besar area yang digunakan atau besar area Luak Gadang Bukik Baka belum didapati luasnya seperti yang dijelaskan oleh UU RI No. 32 Tahun 2009, zona hidup merupakan semua benda yang menyatu dengan ruang, kemampuan, kondisi dan makhluk hidup, termasuk manusia dan perbuatannya yang mengubag kelanjutan aktifitas dan ketentraman manusia serta makhluk hidup lainnya. Yang tergolong kepada zona fisik menurut beberapa referensi adalah:

a. Geografi. Komponen geograsi terdiri dari besar kecilnya suatu area DTW, besar area terbungkus dan juga sekat tata laksana serta sekat semesta.

b. Topografi. Merupakan suatu daerah bagian depan yang terbentuk secara khusus terkonfigurasi dan lahan miring seperti lapangan berbukit dan daerah rangkaian gunung yang terikat ketinggian diatas standar permukaann laut dan lahan umum yang terkonfigurasi.

c. Klimatologi. Temperatur udara, curah hujan, tingkat kelembaban, kuat lemahnya hembusan angin, rata-rata penyinaran matahari dan kombinasi musim tergolong kepada klimatologi.

d. Hidrologi. Daerah aliran sungai, pantai dan laut dikelompokkan kepada karakteristik hidrologi didalamnya termasuk abrasi, sedimentasi, dan arus.

e. Visability. Penampakan dari ujung jalan kanan kiri terbaris pepohonan yang panjang membentuk pemandangan disebut visability.

f. Vegetasi dan Wildlife. Kelansungan hidup flora dan aktifitas liar untuk masa depan harus dipertimbangkan untuk dijaga daerah habitatnya. Umumnya bisa digolongkan kepada tanaman yang melebihi standar, padang rumput serta makluk hidup yang ada didalamnya terdiri dari species flora dan fauna baik yang dikelola secara komersil, konservasi, langka dan berbahaya. 


\section{Aspek Daya Tarik}

Cultural attractions dan man-made attractions merupakan perspektif dari daya tarik yang belum dapat dipenuhi. Pementasan tradisi berupa randai, silat dan lainnya cuma sempat diadakan di Luak Gadang Bukik Baka namun belum mempunyai agenda yang tetap. Namun pementasan buatan memiliki dua rakit bumba, latar pemotretan buatan penduduk dan perahu karet. Dimana latar pemotretasn mempunyai lokasi yang kurang bagus karena penutupi keindahan alam dibelakangnya. Jadi perspektif daya pikat, Luak gadang Bukik Baka belum terwujud sebagau sebuah daya tarik wisata. Menurut Inskeep (1991) tiga kategori daya tarik wisata yaitu: a) Natural attraction, terbentuk dari kejadian alam sehingga menjadi sebuah lingkungan; b) Cultural attraction, terbentuk dari proses kegiatan manusia yang membudaya; dan c) Attraction of special types: merupakan atraksi buatan yang tidak memiliki keterkaitan dengan kedua kategori di atas. Contoh pementasan buatan yaitu theme park, circus, shopping.

\section{Aspek Aksesbilitas}

Pada konteks perspektif aksesbilitas, untuk sightseeing, lanskap alam pada arah jalan ke Luak Gadang dan Bukik Baka sangat nyaman dan menawan. Namun untuk media terusan, baik angkitan maupun komunikasi masih sangat kurang, transportasi umum yang langsung ke Luak Gadang Bukik Baka tidak ada, dan jaringan telekomunikasi dirasakan susah. Hal ini belum sejalan dengan pendapat Bovy dan Lawson (1998) yang mana peran penting dipegang oleh jaringan jalan untuk mendukung kegiatan kepariwisataan yaitu: a) Sebagai aksesbilitas wisatawan, kemudahan komunikasi atraksi rekreasi atau fasilitas dengan pengunjung dan wisatawan; dan b) Sebagai sebuah metode untuk mengamati dan menciptakan suatu tempat yang harus memiliki perencanaan dalam penujukkan keindahan pemandangan selama perjalanan yang dapat disaksikan.

Aspek non fisik ditunjukkan pada peran kedua dalam mendukung aksesbilitas secara keseluruhan yang merupakan faktor penting, dapat berupa ketentraman selama menggunakan jalan dan menuju destinasi berupa waktu yang digunakan dari lokasi asal wisatawan.

\section{Aspek Aktivitas dan Fasilitas}

Pada perspektif fasilitas dan aktifitas diamati dari kesopanan, penduduk jorong Guguak Rangpisang yang santun terhadap wisatawan, menjamu pengunjung dengan ramah, dan penduduk juga membangun semua fasilitas yang tersedia di Luak Gadang Bukik Baka dengan memanfaatkan uang pemberian wisatawan, tetapi fasilitas tersebut masih memiliki kekurangan. Fasilitas yang ada sepertinya harus dilakukan penambahan agar kenyamanan pengunjung tercipta. Sebagaimana yang disampikan oleh Burkart Medik (1987) yang menyatakan penyebab utama yang dapat meransang kunjungan wisatawan ke sebuah kawasan destinasi bukanlah fasilitas, namun fasilitas menciptakan hambatan pada aktivitas rekreasi wisatawan dalam menikmati atrkasi wisata. Pengalaman rekreasi dapat dibentuk dari fungsi fasilitas yang harus bersifat menaggapi serta menyederhanakan akitivitas pengunjung.

\section{Aspek Sosial, Ekonomi dan Budaya}

Pada perspektif ekonomi, sosial penduduk Jorong Guguak Rangpisang belum menekuni Usaha Kecil Menengah guna menggenjot perekonomian dengan memnafaatkan kekayaan alamnya, sehingga belum relevan dengan pernyataan Soekanto (2001) yang menuturkan bahwa ekonomi sosial didefenisikan sebagai 
kondisi seseorang dilingkungan bermasyarakatnya yang diliha dari sudut pandang perbauran, kinerja serta hak-hak dan peranan dalam kaitannya dengan sumber daya.

Pada perspektif budaya dan sosial sosial, penduduk jorong Guguak Rangpisang masih akrab dengan tatacara berbaur dengan sesama penduduk dan mengikuti semua acara, akhirnya tidak terjerumus arah moderenisasi yang umumnya hanya diam dirumah dan tidak bertegur sapa. Penomena itu memberikan peluang bagi wisatawan untuk melihat kehidupan masyarakat Jorong Guguak Rangpisang. Seperti yang diungkapkan oleh Foster (2000) yang mengungkapkan Kebudayaan memiliki pengaruh (cultural influence) yaitu "Para wisatawan tidak memutuskan oleh karena dasar informasi pemrosesan dan juga penilaian. Faktor kebudayaan, masyarakat dan gaya hidup juga mempengaruhi mereka. Kebudayaan yaitu mengacu kepada pakaian tradisional dan suatu kepercayaan terhadap masyarakat, golongan etnik dan agama.

Menurut pengkajian pada setiap perspektif bahwa sekarang Luak Gadang Bukik Baka mempunyai keunggulan wisata yang memiliki kekuatan untuk ditingkatkan menjadi sebuah daya tarik wisata, yakni dapat dilihat aspek fisik mempunyai zona fisik yang baik. Aspek data tarik alam yang indah dan penampilan dari atraksi seni. Perspektif aksesbilitas, pemandangan disepanjang jalan menuju Luak Gadang Bukik Baka yang memiliki suasana menawan dan asri. Aspek fasilitas dan aktifitas, keramahtamahan masyarakat jorong Guguak Rangpisang masih bersosialisasi dengan sesama masyarakat dan wisatawan. Hasil penelahaan ini memiliki kesamaan dan dapat didukung oleh penngkajian sebelumnya yang dilakukan oleh Pramila (2017) dengan hasil "Panorama yang indah dan pemandangan Pulau Nusa Kambangan merupakan sumber daya alami yang dimiliki Pantai Teluk Penyu". Keunggulan yang ada secara sosial berupa kehidupan nelayan yang masih terjaga keasliannya, tempat penjualan ikan, cendramata yang terbuat dari kerang, arus keluar masuk Kapal Tanker di Pelabuhan Tanjung Intan, perahu-perahu nelayan yang terlihat jadul dan tegarnya kilang pertamina. Keunggulan yang dilihat dari segi budaya yaitu perahu naga dan sedekah laut. Penataan kios dengan pembangunan cafetaria merupakan rencana program yang sudah dapat terealisasi.

Selain itu penelitian juga dilakukan oleh Rani (2014) dan hasilnya mendukung penelitian ini. Hasilnya yaitu "Kawasan Lombang pantai perupakan kekayaan negara menyumbangkan persemmbahan untuk pembangunan PAD Kabupaten Sumenep dan otonomi daerah semakin membaik tetapi masih memiliki hambatan yang ditemui dalam upaya pengembangan daya pariwisatayang kejadian di Sumenep, Madura." Dampak positif harus diharapkan datang dari pariwisata Indonesia secara khusus dan Sumenep itu sendiri, sehingga pemerintah harus memperhatikan, warga dan pengusaha dalam pembangunan keunggulan pariwisata di Kabupaten Sumenep, Madura.

\section{Penutup}

Hasil penelitian ini menjelaskan bahwa: Luak Gadang Bukik Baka adalah objek wisata ini dikelola oleh penduduk dan dibuka untuk umum pada April 2018. Pemerintah Kabupaten Agam menyumbangkan vacum suction, bunga dan bibit ikan nila 32.000 ekor. Peningkatan potensi wisata Luak Gadang Bukik Baka yang baru digarap adalah: a) Aspek fisik, yang terdiri dari binatang dan tumbuhan (vegetasi dan wildlife), sifat tanah (geologi), cuaca (klimatologi), permukaan tanah (topografi), pengairan (hidrologi), pepohonan sepanjang jalan (visability); b) Aspek daya tarik, atraksi berupa alam pemandangan di kawasan Luak Gadang Bukik Baka. Atraksi 
buatan rakit bambu, latar pemotretan dan perahu karet, Atraksi Budaya berupa randai dan sejenisnya, pernah dipentaskan oleh warga setempat; c) Aspek aksesbilitas, disebabkan lokasi dikawasan jalan dan Bukit Barisan, dan pemandangan hendak ke Luak Gadang Bukik Baka masih telihat alami dan membuat mata menjadi segar; d) Aspek aktifitas dan fasilitas, dilihat dari keramahtamahan masyarakat jorong Guguak Rangpisang yang ramah terhadap wisatawan maupun sesama masyarakat dan memfasilitasi semua fasilitas yang ada di Luak Gadang Bukik Baka; dan e) Masyarakat jorong Guguak Rangpisang sangat bermasyarakat jika dilihat dari perspektif sosial ekonomi dan budaya, mereka masih suka bergotong royong bahu membahu antar sesamanya. Pemekaran objek wisata Luak Gadang Bukik Baka yang belum digarap: a) Luas area yang terpakai untuk kawasan objek wisata Luak Gadang Bukik Baka jika dilihat dari perspektif Aspek fisik; b) Atraksi budaya dan buatan, atrkasi budaya Luak Gadang Bukik Baka berupa pertunjukan seni dan budaya yang ditampilkan oleh masyarakat seperti randai, silek, tambua dan gambus merupakan uraian dari Aspek daya tarik. Tetapi pertunjukan kebiasaan-kebiasaan ini belum mempunyai agenda pertunjukan yang tetap. Namun spot foto yang dibuat masyarakat, kemudian perahu karet dan atraksi buatan berupa rakit bambu adalah atraksi buatannya. Tapi untuk spot foto menutupi tebing dibelakangnya sehingga terlihat tidak efisien sedangkan tebing tersebut juga merupakan bagian dari pemandangan alam di Luak Gadang Bukik Baka; c) Aspek aksesbilitas, transportasi umum yang alsnung menuju ke Objek wisata Luak Gadang Bukik Baka tidak ada. Begitupun menuju jorong Guguak Rangpisang, transportasi umum hanya sampai jorong pintu Koto, kemudian disambung dengan ojek untuk menuju Luak Gadang Bukik Baka. Sedangkan jaringan internet dan signal handphone yang lancar hanya jaringan telkomsel; dan d) Masyarakat Jorong Gugual Rangpisang tidak memiliki UKM aspek sosial ekonomi dan budaya belum sepenuhnya terpenuhi.

\section{Daftar Pustaka}

Burkart and Medlik. 1974. Tourism Pas, Present, and Future, 2ndedition. London:Heinemann

Foster, Dennis L. 2000. An Introduction Travel \& Tourism. Jakarta: Raja Grafindo Persada

Inskeep, Edward. 1991. Tourism Planning: An Integrated and sustainable Approach. Van Nostrand Reinhold. New York, Inc

Lestari, Rina. 2013. Skripsi. Potensi Objek Wisata Penangkaran Taman Budaya Asam Kumbang Sebagai Salah Satu Upaya Pengembangan Pariwisata di Kota Medan. USU. FIB

Miles, B. Mathew dan Michael Huberman. 1992. Analisis Data Kualitatif Buku Sumber Tentang Metode-metode Baru. Jakarta: UIP.

Moleong, Lexy. J. 2004. Metode Penelitian Kualitatif. Remaja Rosdakarya. Bandung.

Moleong, L.J. 2011. Metodologi Penelitian Kualitatif Edisi Revisi. Bandung: PT. Remaja Rosdakarya

Mustika, Dewi. 2017. Skripsi. Dampak Partisipasi Masyarakat Terhadap Pengembangan Objek Wisata Tarusan Kamang Agam. UMSB. FP

Noor, Juliansyah. 2011. Metodologi Penelitian: Skripsi, Tesis, Disertasi, Dan. Karya Ilmiah. Jakarta: Kencana.

Soekanto, Soerjono. 2001. Hukum Adat Indonesia. Jakarta: PT. Raja Grafindo. Persada. 
Spillane, James. 1994. Pariwisata Indonesia, Siasat Ekonomi dan Rekayasa. Kebuadayaan. Kanisius. Yogyakarta

Sugiyono. 2015. Metode Penelitian Kuantitatif. Kualitatif dan R\&D. Bandung Alfabeta. 